\title{
Treating simple benign esophageal strictures with Savary-Gilliard dilators: is the rule of three still necessary?
}

\author{
Carlos ROBLES-MEDRANDA, Roberto OLEAS, Haydee ALVARADO-ESCOBAR, Miguel PUGA-TEJADA, \\ Jorge BAQUERIZO-BURGOS and Hannah PITANGA-LUKASHOK
}

Received 9/1/2019

\begin{abstract}
Background - Bougies dilation is considered an effective technique for the treatment of simple benign esophageal strictures. The "rule of three" has been advocated to prevent reported adverse events such as bleeding and perforation. However, adherence to this rule has increased the cost and duration of treatment. Objective - To demonstrate the safety and long-term benefits of progressive bougie dilations until reaching $15 \mathrm{~mm}$ (45Fr) in one single session endoscopy with non-adherence to the rule of three. Methods - A retrospective analysis of a prospectively collected data of patients with simple benign esophageal strictures treated with multiple progressive bougie dilators until reaching $15 \mathrm{~mm}(45 \mathrm{Fr})$ in one single session. Results - The median age was 58 years (range 28-89), and $83.3 \%$ of patients were female. The main presenting symptom was dysphagia for solids in $11 / 12$ cases $(91.6 \%)$. The cause of their simple benign esophageal stricture was distributed as follows: 7/12 esophageal webs, 2/12 peptic stenosis, $2 / 12$ Schatzki rings and one caustic injury. $75 \%$ required only one session for clinical success. No serious adverse events were described. No recurrence of symptoms was noted in a median follow-up of 20 months. Conclusion - The rule of three in patients with simple benign esophageal strictures secondary to esophageal webs, Schatzki rings and peptic strictures treated with Savary-Gilliard dilators is not necessary, showing good clinical results. Prospective studies with more patients are necessary.
\end{abstract}

HEADINGS - Esophageal stenosis. Dilatation. Esophagoscopy.

\section{INTRODUCTION}

Benign esophageal strictures (BES) may be caused by Schatzki rings, esophageal webs, radiation injuries, caustic ingestions, and peptic and anastomotic stenosis ${ }^{(1)}$. Benign esophageal strictures are classified as simple or resistant according to their therapeutic feasibility. Simple benign esophageal strictures (SBES) may be relieved with one to three dilation sessions, while resistant benign esophageal strictures (RBES) may be difficult to treat, requiring multiple dilation sessions, corticosteroid injections, incisional therapy, or temporary stent placement ${ }^{(2)}$.

Savary-Gilliard dilation (SGD) is considered an effective technique for the treatment of SBES. Adverse events related to dilation include perforation and bleeding. Major adverse events occurred in fewer than $1 \%$ of patients undergoing dilation sessions (bougie or balloon dilation), with perforation occurring in $0.5 \%{ }^{(3)}$.

Over the last 30 years, the "rule of three" was implemented to preclude overaggressive dilation and prevent adverse events. This rule consists of performing dilations without increasing the lumen diameter by more than $3 \mathrm{~mm}$ per session/day ${ }^{(4)}$. However, following this rule increased the number of endoscopic dilations required and the health care-related costs.

The aim of the present study is to demonstrate the safety and long-term benefits of progressive bougie dilations until reaching $15 \mathrm{~mm}(45 \mathrm{Fr})$ in one single session endoscopy with non-adherence to the rule of three.

\section{METHODS}

\section{Patient selection}

A retrospective analysis of a consecutively collected database was performed to identify patients who underwent SGD at a tertiary referral center from December 2012 to December 2014. The study protocol was approved by the Institutional Review Board. Written informed consent for each procedure was routinely obtained from each patient.

Medical records, endoscopy, and fluoroscopy findings were reviewed by two gastroenterologists for defining Simple Benign Esophageal Strictures (SBES). SBES was defined as a focal $<20$ $\mathrm{mm}$ in length esophageal strictures, meanwhile RBES was defined as longer than $20 \mathrm{~mm}$, irregular and with a narrow diameter or requiring more than 5 endoscopic therapies.

Patients were excluded if they were less than 18 years old, patients with incomplete medical records, malignant dysphagia, RBES or if they were treated with balloon dilation. Patients with prior endoscopic treatment before the endoscopic dilation with Bougies were excluded for analysis.

The demographic and clinical data of each patient including gender, age at diagnosis, stricture etiology was extracted from medical records. Any adverse event such as bleeding and perforation and the number of sessions required were reviewed in endoscopy reports. Clinical and technical success was reviewed in each case. Technical success was defined as the achievement of $15 \mathrm{~mm}$ dila- 
tion with the SGD technique. Clinical success was defined as the lack of recurrence of dysphagia during follow-up and no need for endoscopic interventions for at least 6 months. Mean follow-up time was defined in months counting since the first SGD and the last clinic visit.

\section{Technique procedure}

Under unconscious sedation with intravenous Propofol, SavaryGilliard dilations (SGD) were performed. All procedures were performed without fluoroscopy guidance, as reported by Kabbaj et al. ${ }^{(5)}$. A guide-wire was placed endoscopically. In one single session dilations using bougies were performed until reaching $15 \mathrm{~mm}$ (45Fr) in all cases, with a total of 294 dilations in all cases. The set implemented was one formed by 7 bougies: $5 \mathrm{~mm}(15 \mathrm{Fr}), 7 \mathrm{~mm}$ (21Fr), 9mm (27Fr), $11 \mathrm{~mm}$ (33Fr), $12.8 \mathrm{~mm}$ (38Fr), 14mm (42Fr), and $15 \mathrm{~mm}(45 \mathrm{Fr})$ subsequently (FIGURES 1 and 2). After dilation, the esophageal mucosa was inspected for ruling out any adverse event. Patients were given an appointment for a visit to the clinic usually 3-6 weeks after SGD.

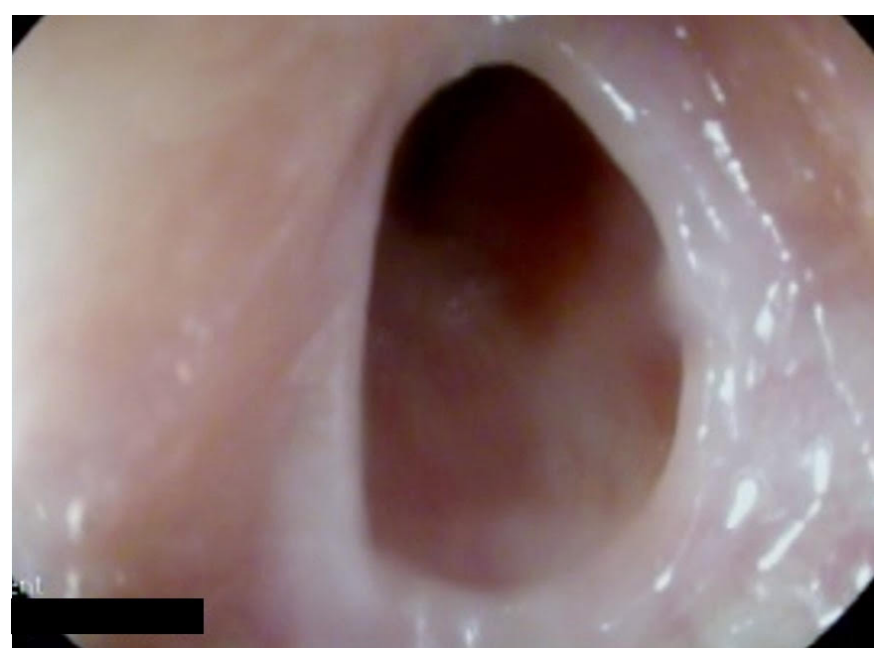

FIGURE 1. Simple benign esophageal stricture in the upper part of the esophagus in case 2.

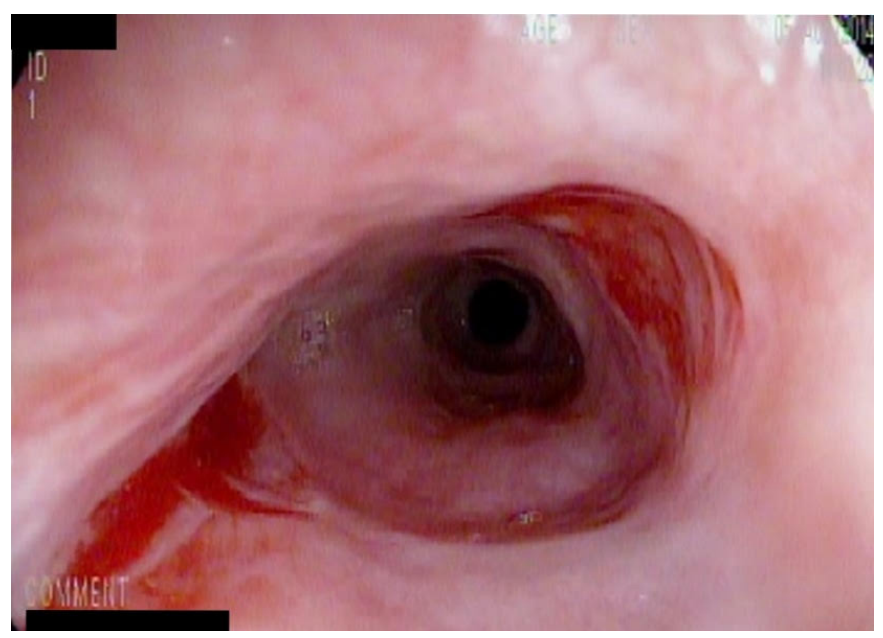

FIGURE 2. Simple benign esophageal stricture after one single-session dilations using bougies until reaching $15 \mathrm{~mm}(45 \mathrm{Fr})$.

\section{Statistical analysis}

Continuous variables were analyzed according to their statistical distribution calculated by Shapiro-Wilk or KolmogorovSmirnov tests as indicated. Normally distributed data are represented as means (standard deviation), and skewed distributed data are represented as medians (interquartile range). Qualitative variables are represented as frequencies (\%). Statistical analyses were performed using R v3.4.3 (R Foundation for Statistical Computing, Vienna, Austria).

\section{RESULTS}

A total of 37 cases were extracted from the prospectively collected database by using the filter "esophageal dilation". Thirteen cases with SBES treated with SGD were included after reviewing all medical records by two gastroenterologists; however, 12 patients fulfilled inclusion criteria and were analyzed (TABLE 1). Patients included for analysis have no history of previous endoscopic treatment. Median age was 58 years old (range: 28-89), 10 out of 12 $(83.3 \%)$ were female. The main presenting symptom was dysphagia for solids in 11/12 cases $(91.6 \%)$. Causes of SBES were distributed as follow: 7/12 esophageal webs, 2/12 peptic stenosis, 2/12 Schatzky rings and one caustic injury.

TABLE 1. Baseline characteristics of patients with simple benign esophageal strictures who underwent dilations with bougies with non-adherence to the rule of three.

\begin{tabular}{|c|c|c|c|c|c|c|c|}
\hline Case & $\begin{array}{l}\text { Age } \\
(y / o)\end{array}$ & Sex & Etiology & Symptoms & $\begin{array}{l}\text { Number } \\
\text { of } \\
\text { dilation } \\
\text { sessions } \\
\text { for CR* }\end{array}$ & $\begin{array}{l}\text { Size of } \\
\text { the SGD } \\
\text { from } \\
(\mathrm{mm})-\text { to } \\
(\mathrm{mm})\end{array}$ & $\begin{array}{c}\text { Adverse } \\
\text { events }\end{array}$ \\
\hline 1 & 28 & $\mathrm{~F}$ & $\begin{array}{l}\text { Caustic } \\
\text { injury }\end{array}$ & $\begin{array}{l}\text { Dysphagia } \\
\text { for solids }\end{array}$ & 1 & $7-15$ & No \\
\hline 2 & 54 & $\mathrm{~F}$ & $\begin{array}{c}\text { Esophageal } \\
\text { web }\end{array}$ & $\begin{array}{l}\text { Dysphagia } \\
\text { for solids }\end{array}$ & 1 & $9-15$ & No \\
\hline 3 & 68 & $\mathrm{~F}$ & $\begin{array}{c}\text { Esophageal } \\
\text { web }\end{array}$ & $\begin{array}{l}\text { Dysphagia } \\
\text { for solids }\end{array}$ & 1 & $7-15$ & No \\
\hline 4 & 89 & $\mathrm{~F}$ & $\begin{array}{c}\text { Esophageal } \\
\text { web }\end{array}$ & $\begin{array}{l}\text { Dysphagia } \\
\text { for solids }\end{array}$ & 4 & $7-15$ & No \\
\hline 5 & 58 & $\mathrm{~F}$ & $\begin{array}{l}\text { Schatzki } \\
\text { ring }\end{array}$ & $\begin{array}{l}\text { Dysphagia } \\
\text { for solids }\end{array}$ & 4 & $8-15$ & No \\
\hline 6 & 75 & M & $\begin{array}{l}\text { Peptic } \\
\text { injury }\end{array}$ & $\begin{array}{l}\text { Dysphagia } \\
\text { for solids } \\
\text { and liquids }\end{array}$ & 4 & $7-15$ & No \\
\hline 7 & 48 & $\mathrm{~F}$ & $\begin{array}{c}\text { Esophageal } \\
\text { web }\end{array}$ & $\begin{array}{l}\text { Dysphagia } \\
\text { for solids }\end{array}$ & 1 & $7-15$ & No \\
\hline 8 & 34 & $\mathrm{~F}$ & $\begin{array}{l}\text { Schatzki } \\
\text { ring }\end{array}$ & $\begin{array}{l}\text { Dysphagia } \\
\text { for solids }\end{array}$ & 1 & $7-15$ & No \\
\hline 9 & 78 & M & $\begin{array}{l}\text { Peptic } \\
\text { injury }\end{array}$ & $\begin{array}{l}\text { Dysphagia } \\
\text { for solids }\end{array}$ & 1 & $7-15$ & No \\
\hline 10 & 65 & $\mathrm{~F}$ & $\begin{array}{c}\text { Esophageal } \\
\text { web }\end{array}$ & $\begin{array}{l}\text { Dysphagia } \\
\text { for solids }\end{array}$ & 1 & $7-15$ & No \\
\hline 11 & 70 & $\mathrm{~F}$ & $\begin{array}{l}\text { Esophageal } \\
\text { web }\end{array}$ & $\begin{array}{l}\text { Dysphagia } \\
\text { for solids }\end{array}$ & 1 & $7-15$ & No \\
\hline 12 & 52 & F & $\begin{array}{c}\text { Esophageal } \\
\text { web }\end{array}$ & $\begin{array}{l}\text { Dysphagia } \\
\text { for solids }\end{array}$ & 1 & $7-15$ & No \\
\hline
\end{tabular}


Median esophageal lumen diameter previous SGD dilation was 7, (range: 7-9). Included cases had a median of $8 \mathrm{~mm}$, range (6-7) in increased diameter after SGD dilation. All patients reached a $15 \mathrm{~mm}$ (45Fr) diameter.

No serious adverse events were reported among these patients. After dilation, the esophageal mucosa was inspected endoscopically in order to rule out any possible adverse event. Patients were seen for a follow-up visit in the clinic, usually 3-6 weeks after SGD. The median follow-up time was 20 months. Recurrence of symptoms was not reported during the follow-up period. The mean number of sessions was 1 (range 1-4). One single session was required in $75 \%$ of cases to achieve clinical success.

\section{DISCUSSION}

Benign esophageal strictures have multiple etiologies and are associated with a negative impact on the quality of life; they are associated with malnutrition, weight loss and aspiration. Endoscopic dilation with bougies or balloons is the standard treatment for such strictures ${ }^{(6)}$. However, $30 \%$ to $40 \%$ will recur during long-term follow-up, requiring repeated dilation or surgery ${ }^{(1)}$.

The rule of three, theoretically applicable to SGD alone, is intended to preclude overaggressive dilation. This rule was first described in 1986 to avoid adverse events due to the limitations at that time for treating them endoscopically. Moreover, this rule was not evidence-based, and few data regarding non-adherence to this rule for treating SBES are available.

Landon et al., were the first to describe dilatations from $6 \mathrm{~mm}$ to $15 \mathrm{~mm}$ in a single session without observing severe adverse events ${ }^{(7)}$. Grooteman et al., in a retrospective analysis, showed that nonadherence to the "rule of three" is not associated with an increased risk of adverse events; however, this technique was applied only in $13 \%$ of patients included in the study, and most adverse events were observed in patients with malignant esophageal strictures ${ }^{(3)}$.

A lack of current evidence in the endoscopic treatment of SBES, considering that available randomized clinical trials were published before the 2000 s, encourage investigators to evaluate the effectiveness and safety of progressive bougie dilations until reaching $15 \mathrm{~mm}$ (45Fr) in a single session endoscopy in patients SBES.

Recently, a meta-analysis found no difference between bougie and balloon dilations of SBES in the symptoms relief, recurrence of symptoms, bleeding, and perforation ${ }^{(8)}$. However, the different etiologies for SBES, the different types of bougies, and the different interval between dilation sessions make all studies high heterogeneous.

Caustic injuries and post-radiotherapy stricture carry a greater involvement of deeper layers of the esophageal wall, such as the muscularis propria, that makes a stricture more complex to treat and increase the risk for perforation. Whereas, strictures compromising only a superficial esophageal layer such as esophageal webs,
Schatzki ring and peptic strictures, are prompt to respond better to dilation ${ }^{(8)}$. In our study, most of the patients have esophageal webs as the etiology of SBES, and only one patient has a caustic stricture. Therefore, the etiology of the SBES must be considered before defining the most adequate dilation technique.

The findings in the present study are relevant for several reasons. All patients fulfilled the definition of SBES accepted in the literature, excluding RBES, malignant strictures and other possible confounders. We also presented data with a mean follow-up of 20 months, demonstrating the long-term benefits of the technique. The authors recommend that the aggressiveness of the dilations be adapted to the stricture etiology and esophageal layer's involvement, intended to generate radial forces, longitudinal forces, or both, to tear the stricture. We suggest that back-up treatment options for treating adverse events be available in the endoscopy unit when using bougies dilators.

The dilation technique implemented in our patients demonstrated the safety and long-term benefits of progressive bougie dilations until reaching $15 \mathrm{~mm}$ (45Fr) in a single session endoscopy with non-adherence to the rule of three in SBES. Our results are consistent with other authors that found that the "rule of three" does not need to be a rule ${ }^{(3,9)}$. However, the etiology of the stricture and the involvement of the esophageal layers (superficial or deep) must be considered before deciding the most appropriate dilation technique and the adherence to the rule of three necessity.

\section{CONCLUSION}

The rule of three in patients with simple benign esophageal strictures secondary to esophageal webs, Schatzki rings and peptic strictures treated with Savary-Gilliard dilators is not necessary, showing good clinical results. However, prospective studies with more patients are needed to confirm whether the rule of three remains necessary for specific simple benign esophageal strictures etiologies.

\section{Authors' contribution}

Robles-Medranda $\mathrm{C}$ and Pitanga-Lukashok $\mathrm{H}$ designed the study. Alvarado-Escobar H collected the patient's clinical data. Puga-Tejada M, Baquerizo-Burgos J and Oleas R analyzed the data and wrote the paper.

\section{Orcid}

Carlos Robles Medranda. Orcid: 0000-0003-2434-3369.

Roberto Oleas. Orcid: 0000-0001-9810-4745.

Haydee Alvarado Escobar. Orcid: 0000-0003-0383-8370.

Miguel Puga Tejada. Orcid: 0000-0001-8853-0847.

Jorge Baquerizo Burgos. Orcid: 0000-0002-6741-4211.

Hannah Pitanga Lukashok. Orcid: 0000-0002-4364-1321. 
Robles-Medranda C, Oleas R, Alvarado-Escobar H, Puga-Tejada M, Baquerizo-Burgos J, Pitanga-Lukashok H. Tratamento das estenoses esofágicas benignas simples com dilatadores de Savary-Gilliard: ainda é necessária a regra de três? Arq Gastroenterol. 2019;56(1):95-8.

RESUMO - Contexto - A dilatação por velas é considerada uma técnica eficaz para o tratamento de estenoses esofágicas benignas simples. A "regra de três" tem sido defendida para prevenir eventos adversos relatados, como sangramento e perfuração. No entanto, a adesão a esta regra aumentou o custo e a duração do tratamento. Objetivo - Demonstrar a segurança e os benefícios de longo prazo das dilatações progressivas por velas até chegar a $15 \mathrm{~mm}$ (45Fr) em uma única sessão de endoscopia com não adesão à regra de três. Métodos - Uma análise retrospectiva de dados coletados prospectivamente de pacientes com estenoses esofágicas benignas simples tratadas com múltiplos dilatadores de velas progressivas até atingir $15 \mathrm{~mm}$ (45Fr) em uma única sessão. Resultados - A mediana de idade foi de 58 anos (variação de 28-89) e 83,3\% dos pacientes eram do sexo feminino. O principal sintoma de apresentação foi a disfagia para sólidos em 11/12 casos (91,6\%). A causa da estenose esofágica benigna simples foi distribuída como segue: 7/12 membranas esofágicas, 2/12 estenose péptica, 2/12 anéis de Schatzki e um ferimento cáustico. 75\% necessitaram apenas de uma sessão para o sucesso clínico. Não foram descritos eventos adversos graves. Nenhum retorno dos sintomas foi anotado em uma continuação mediana de 20 meses. Conclusão - A regra de três em pacientes com as estenoses esofágicas benignas simples secundárias às membranas esofágicas, os anéis de Schatzki e as estenoses péptica tratadas com os dilatadores de Savary-Gilliard não é necessária, mostrando bons resultados clínicos. Estudos prospectivos com mais pacientes são necessários.

DESCRITORES - Estenose esofágica. Dilatação. Esofagoscopia.

\section{REFERENCES}

1. Lew RJ, Kochman ML. A review of endoscopic methods of esophageal dilation. J Clin Gastroenterol. 2002;35:117-26.

2. de Wijkerslooth LR, Vleggaar FP, Siersema PD. Endoscopic management of difficult or recurrent esophageal strictures. Am J Gastroenterol. 2011;106:2080-91.

3. Grooteman KV, Wong Kee Song LM, Vleggaar FP, Siersema PD, Baron TH Non-adherence to the rule of 3 does not increase the risk of adverse events in esophageal dilation. Gastrointest Endosc. 2017;85:332-7.

4. Boyce HW. Esophageal dilation. Gastroenterol Endosc News. 1986:1-3.

5. Kabbaj N, Salihoun M, Chaoui Z, Acharki M, Amrani N. Safety and outcome using endoscopic dilatation for benign esophageal stricture without fluoroscopy. World J Gastrointest Pharmacol Ther 2011;2:46-9.
6. Siersema PD. Treatment options for esophageal strictures. Nat Clin Pract Gastroenterol Hepatol. 2008;5:142-52.

7. Langdon DF. The rule of three in esophageal dilation. Gastrointest Endosc. 1997;45:111.

8. Josino IR, Madruga-Neto AC, Ribeiro IB, Guedes HG, Brunaldi VO, de Moura DTH, et al. Endoscopic Dilation with Bougies versus Balloon Dilation in Esophageal Benign Strictures: Systematic Review and Meta-Analysis. Gastroenterol Res Pract. 2018;2018:5874870.

9. Rodrigues-Pinto E, Pereira P, Ribeiro A, Lopes S, Moutinho-Ribeiro P, Peixoto A, et al. Risk factors associated with refractoriness to esophageal dilatation for benign dysphagia. Eur J Gastroenterol Hepatol. 2016;28:684-8. 